\title{
Development of allometric relationships for estimate above ground biomass of trees in the tropical abandoned land
}

\author{
KARYATI ${ }^{1, \bullet}$, KUSNO YULI WIDIATI $^{1}$, KARMINI $^{2, v v}$, RACHMAD MULYADI $^{1}$ \\ ${ }^{1}$ Faculty of Forestry, Universitas Mulawarman. Jl. Ki Hajar Dewantara, Kampus Gunung Kelua, Samarinda 75123, East Kalimantan, Indonesia. \\ Tel.: +62-541-735089, 749068, Fax.: +62-541-735379, `email: karyati@fahutan.unmul.ac.id ; karyati.hanapi@yahoo.com \\ ${ }^{2}$ Faculty of Agriculture, Universitas Mulawarman. Jl. Pasir Balengkong, Kampus Gunung Kelua, Samarinda 75123, East Kalimantan, Indonesia. \\ Tel.: +62-541-749161, Fax.: +62-541-738341, ^•email: karmini@faperta.unmul.ac.id, karmini.kasiman@yahoo.com
}

Manuscript received: 29 September 2019. Revision accepted: 10 November 2019

\begin{abstract}
Karyati, Widiati KY, Karmini, Mulyadi R. 2019. Development of allometric relationships for estimate above ground biomass of trees in the tropical abandoned lands. Biodiversitas 20: 3508-3516. The abandoned lands have important role in the ecological function as well as carbon sequestration. The allometric equations to estimate above ground biomass in abandoned land are still limited available. This study objective was to develop allometric relationships between tree size variables (diameter at breast height (DBH) and tree height) and leaf, branch, trunk, and total above ground biomass (TAGB) in abandoned land in East Kalimantan, Indonesia. The correlation coefficients between stem DBH and tree height to leaf and branch indicating a relatively weak relationship. The moderately strong relationships were showed by DBH and tree height to trunk and TAGB. The specific allometric equation of above ground biomass for different land use and land type is needed to estimate the accurate TAGB in the site.
\end{abstract}

Keywords: Abandoned land, allometric equation, biomass, destructive method

\section{INTRODUCTION}

The forest degradation process with respect to selective logging, forest fire, and abandonment dynamics occurs over large areas in tropical forests (Pinheiro et al. 2016). The National Land Affairs Agency identified 7.3 million hectares lands in Indonesia as abandoned lands in 2011 and about 4.8 million hectares were stated as abandoned lands. This area of abandoned lands increases from 2007 as much as 7.1 million hectares outside forest area (Nurlinda et al. 2014). The abandoned land area in East Kalimantan was about 3 million hectares. The abandoned lands provide habitat rotation to succession process in primary-secondary forests that will increase biodiversity (Chokkalingam et al. 2001). The plant composition, diversity, and growth during fallow periods after shifting cultivation was resulted from complex interaction between condition and factor before and after fallow periods, such as disturbance, land history, land management, tree and seed source composition from soil or surrounding forest, soil fertility, and climate factor (Kendawang et al. 2007; Awang Noor et al. 2008; Van Do et al. 2010).

Forest-based land-use systems sequester carbon dioxide by storing carbon stored in their biomass (Gorte 2007; Roshetko et al. 2002). The carbon stock in old age stand could different compared to carbon stock in second-growth stand that replaces it, cause woody biomass in an area could not describe in net ecosystem productivity (Janisch and Harmon 2002). Biomass dynamics in tropical forests play important role in evaluation of global carbon cycle and global climate change (Seiler and Crutzen 1980; Fearnside 1997). During the early succession process, amount of stand biomass increases fastly (Selaya et al. 2007). The carbon sequestration of forest area change constantly with vegetation growth, dead, and decomposition (Gorte 2007); species composition, age structure, and forest health (Harmon et al. 1990). Carbon stock at stand in the surface soil and standing tree mass could represent less than $1 \%$ to $60 \%$ from total carbon stock of forest ecosystem (Curtis 2008). Carbon stock of fertile soils is higher which could influence carbon stock storage at vegetation biomass (Hairiah and Rahayu 2007).

Biomass is generally expressed in terms of dry weight and on occasion may be given in terms of ash-free dry weight (Moore and Chapman 1986). The 'scaling' relationships, by which the ratios between different aspects of tree size change when small and large trees of the same species are compared generally known as 'allometric' relations (Hairiah et al. 2001). The previous studies had been developed allometric equations to estimate above ground biomass (AGB) in the secondary forests (Nelson et al. 1999; Ketterings et al. 2001; Hashimoto et al. 2004; Kiyono and Hastaniah 2005; Sierra et al. 2007; Kenzo et al. 2009a,b; Karyati et al. 2019). However, the allometric equations to estimate AGB in abandoned lands are still rare reported. The objective of this study was to develop allometric equations for estimation AGB in fallow lands. Information on the allometric relationships could predict biomass and carbon stock in lands after abandonment. 


\section{MATERIALS AND METHODS}

\section{Study site}

The study was carried out in Salo Cella Village, Muara Badak Sub-district, Kutai Kartanegara Districts, East Kalimantan Province, Indonesia (Figure 1). This site was located at $0^{\circ} 17^{\prime} 18.7^{\prime \prime} \mathrm{S} 117^{\circ} 18^{\prime} 08.2^{\prime \prime} \mathrm{E}$. The study site was abandoned land after selective logging about 30 years ago. Muara Badak Sub-district has $939.09 \mathrm{~km}^{2}$ wide with population of 57,712 persons including 13 villages. Salo Cella Village is about $10 \mathrm{~km}$ from the capital of Subdistrict. The capital of subdistrict was Muara Badak Ulu with $16 \mathrm{~m}$ height Above Mean Sea Level (AMSL). Muara Badak received average amount of $141 \mathrm{~mm}$ in rainfall and 11 rain days in 2017 (Statistics Kutai Kartanegara Regency 2018). Most of the population in this village were farmers' livelihoods. Muara Badak is administratively bordered with Marang Kayu Sub-district at north side, Anggana Subdistrict Samarinda City at south side, Makassar Strait at east side, and Tenggarong Seberang Sub-district at west side. Muara Badak is one of oil and gas producer. This has also big potency in fishery and plantation sectors. The area was covered by lowland mixed dipterocarp forest.
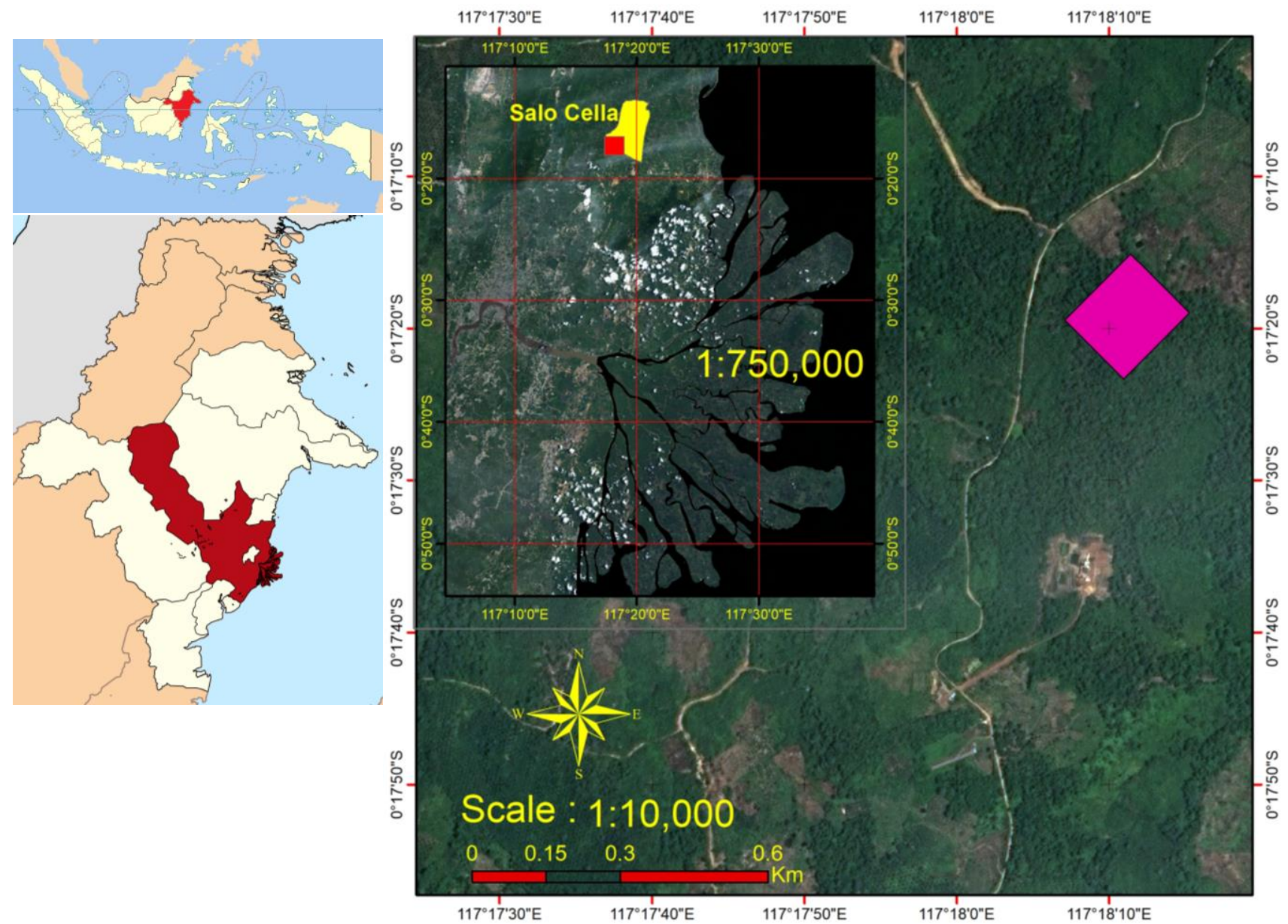

Imagery Map Reference:

SPOT 6 (LAPAN, 2016)

Copied and Processed by: Rachmad Mulyadi (2019)

Soil, Water and Climate Laboratory

Forestry Faculty, Mulawarman University
Legend $\square$ RESEARCH PLOT

Information:

Research Plot is Located at

Salo Cella Village,Kutai Kartanegara East Kalimantan

Condition of Shrub Land Cover

Figure 1. Map of study site in Salo Cella Village, Kutai Kartanegara Districts, East Kalimantan Province, Indonesia 


\section{Data collection}

Assessment of biomass in the field

Thirty sample trees were chosen in abandoned land. The sample trees were selected to obtain the representative species of land after abandonment. The selection of sample trees was based on consideration of the species and DBH. The standing DBH $(1.3 \mathrm{~m})$ of selected trees were measured using diameter tape. Measurement of the total height of the sample tree was completed once the tree had fallen. Fellings sample trees were conducted by following the harvesting rules. The harvested trees were divided into several fractions which every tree fraction was 1-meter length. Then, parts of trees were separated into leaves and twigs (hereafter called leaves), branches, and main stems in the field as shown in Figure 2.

Dividing sample tree fractions was accomplished with the following criteria (Ministry of Forestry Indonesia, 2011): (i) Dividing sample tree fractions was done to separate parts of tree biomass including leaves, branches, and stem. The flower and fruit parts were not included in the observation, because very few sample trees that have flower and fruit during observation. (ii) Dividing sample tree fraction to be weighed needs to consider the capacity of the available scales. (iii) Especially for the stem fraction, the stem was divided into several sections (sub-fractions of the stem) taking into account the shape, uniformity, and weight of the pieces.

The fresh weight of all fractions was taken by a suitable scale in the field. The disk samples of trunk with $2-5 \mathrm{~cm}$ thick were were collected as many as three disk samples if the harvested trees had less than 10 fractions and four disk samples if more than 10 fractions. Five branch samples of $20-30 \mathrm{~cm}$ in length and five-leaf samples of 100-300 grams in weight were taken from each sample tree. Figure 3 illustrates tree components and the position of sub-sample being taken for AGB assessment. The wood density of each sample tree was conducted from the various literature.

\section{Analysis of dry-weight in the laboratory}

Before oven-dried, all samples were air-dried in the laboratory to determine the moisture content. Then, samples of stem and branch fractions were dried in an oven at a temperature $105^{\circ} \mathrm{C}$ for 96 hours until reaching a constant weight. Samples of leaves were dried in an oven at temperature of $80^{\circ} \mathrm{C}$ for 48 hours until constant weight was reached. Weighing the samples of each fraction was performed using an analytical digital weighing scale after drying them in an oven.

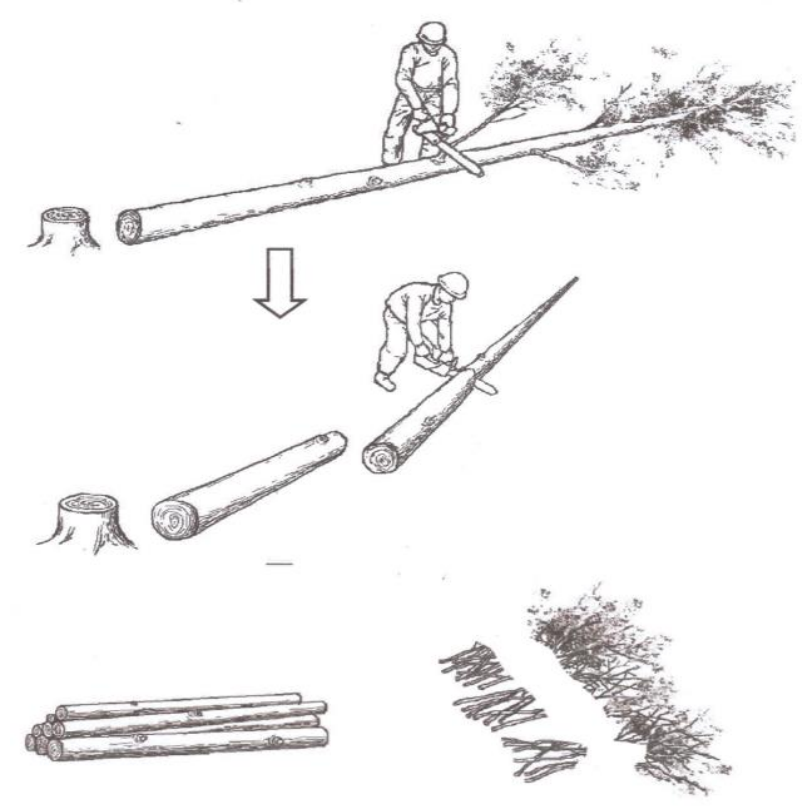

Figure 2. Dividing the trees (Ministry of Forestry Indonesia 2011)

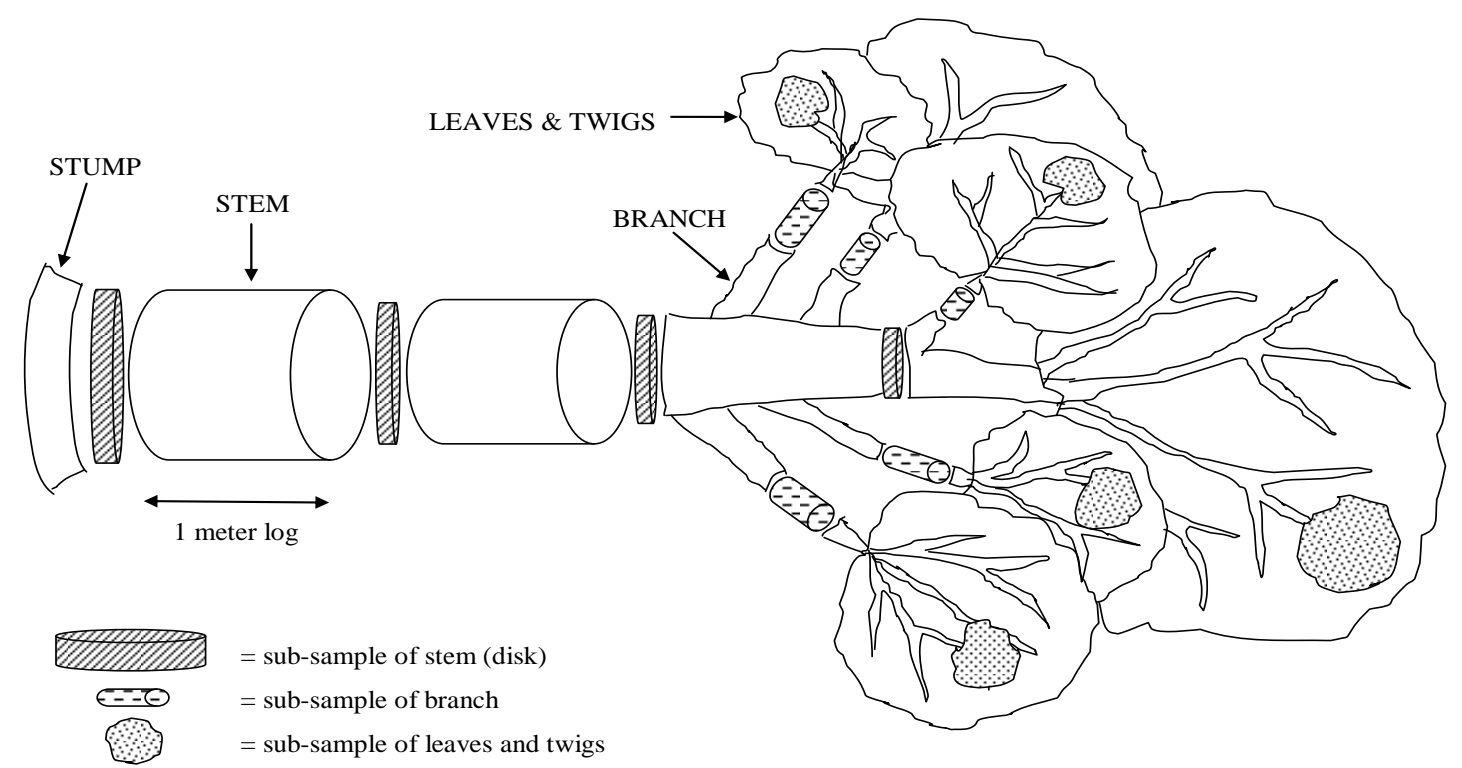

Figure 3. Illustration of tree components and the position of sub-sample being taken (Karyati 2013) 


\section{Data analysis}

The total oven-dry weight of each tree part was determined using the following formula (Hairiah et al. 2001; Hairiah and Rahayu 2007; Ministry of Forestry Indonesia 2011):

$\mathrm{dw}=(\mathrm{sdw} \times \mathrm{fw}) / \mathrm{sfw}$

Where: $\mathrm{dw}=$ total dry weight $(\mathrm{kg})$; $\mathrm{sdw}=$ dry weight of the sample $(\mathrm{g})$; fw = total fresh weight $(\mathrm{kg}) ; \mathrm{sfw}=$ fresh weight of the sample $(\mathrm{g})$.

The five selected allometric equations of AGB were tested (Equations 2-6):

$$
\begin{aligned}
& y=a+b x \\
& y=a x^{b} \\
& y=a+b(\ln x) \\
& (\ln y)=a+b x \\
& (\ln y)=a+b(\ln x)
\end{aligned}
$$

Where: $\mathrm{y}=$ total dry weight or biomass of each plant part, such as trunk, branch, leaf, and total above ground biomass (TAGB) $(\mathrm{kg}) ; \mathrm{x}=$ diameter at breast height $(\mathrm{DBH}$, $\mathrm{cm})$, total height $\left(\mathrm{H}\right.$, meter), and $\left(\mathrm{DBH}^{2} \times \mathrm{H}\right)\left(\mathrm{cm}^{2} \mathrm{~m}\right)$; ' $\mathrm{a}$ ' and ' $b$ ' = coefficients estimated by regression.

All regression analysis was carried out using SPSS version 18 for windows (SPSS Japan, Tokyo, Japan). The $R^{2}$ value and $P$ value were determined to evaluate precision among all tested allometric equations. The indices of relative errors such as mean prediction error (MPE), mean relative error (MRE), and mean relative absolute error (MRAE) were also assessed for model evaluation.

\section{RESULTS AND DISCUSSION}

\section{Selected samples of trees}

Thirty trees with DBH of $\geq 15 \mathrm{~cm}$ were harvested and measured to determine above ground parts in the study site as represented in Table 1. The DBH and height classes of selected sample trees for assessment AGB are illustrated in Figure 4. The DBH range was 16.0-32.6 cm and height was 9.3-22.7 $\mathrm{m}$ for selective sample trees. The relationship between $\mathrm{DBH}$ and total height of sample trees for assessment AGB in the study site is presented in Figure 5. The illustration showed that an increase in DBH was followed by an increase in total height. The equations of this relationship was " $\mathrm{H}=0.4642(\mathrm{DBH})+3.2344$ " $(\mathrm{n}=30$; $\mathrm{R}^{2}=0.3339$ ). As stated ' $\mathrm{H}$ ' is total height $(\mathrm{m})$ and ' $\mathrm{DBH}$ ' is diameter at breast height $(\mathrm{cm})$.

\section{Tree variables}

Pearson's correlation between DBH, height, wood density and branches biomass, trunk biomass, TAGB and parameters of destructive biomass are summarized in Table 1. The minimum and maximum weight of branches biomass, trunk biomass, and TAGB were $3.92-34.18 \mathrm{~kg}$; $12.84-296.72 \mathrm{~kg}$, and $34.28-308.98$ respectively. The DBH of sample trees ranged from $16.00-32.00 \mathrm{~cm}$, with the height ranged $9.30-22.70 \mathrm{~m}$. The wood density of sample trees ranged $0.37-0.69 \mathrm{~g} \mathrm{~cm}^{-3}$. The result showed that there were strong correlation $(P<0.01)$ among trunk biomass to $\mathrm{DBH}$ and tree height as well as TAGB and tree height. The correlation $(P<0.05)$ was shown by TAGB and DBH. The strong correlation $(P<0.01)$ was also shown between $\mathrm{DBH}$ and tree height. However, the leaf and branch biomass were not correlated with $\mathrm{DBH}$ and tree height significantly $(P>0.05)$. In addition, the wood density was not also correlated to plant part biomass (leaf, branch, trunk, and TAGB) and tree dimensions (DBH and height).

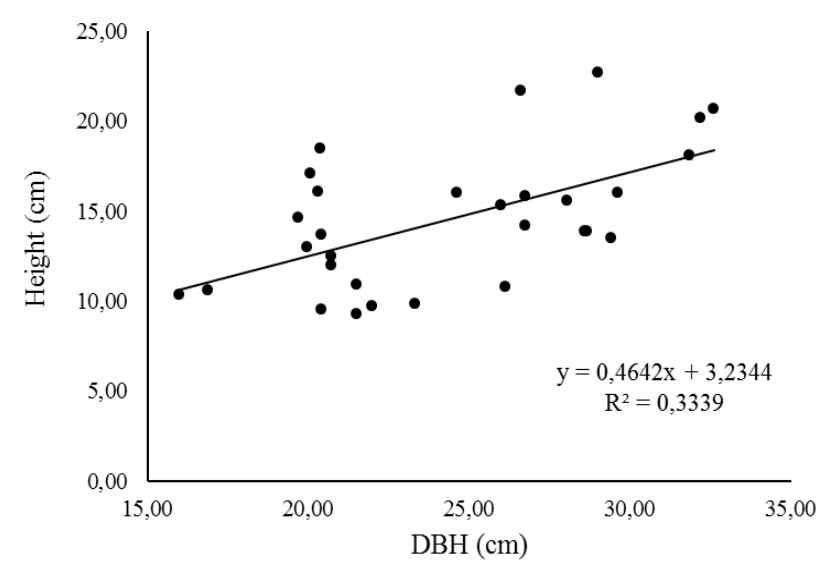

Figure 5. The DBH and total height of sample trees to developed allometric equations

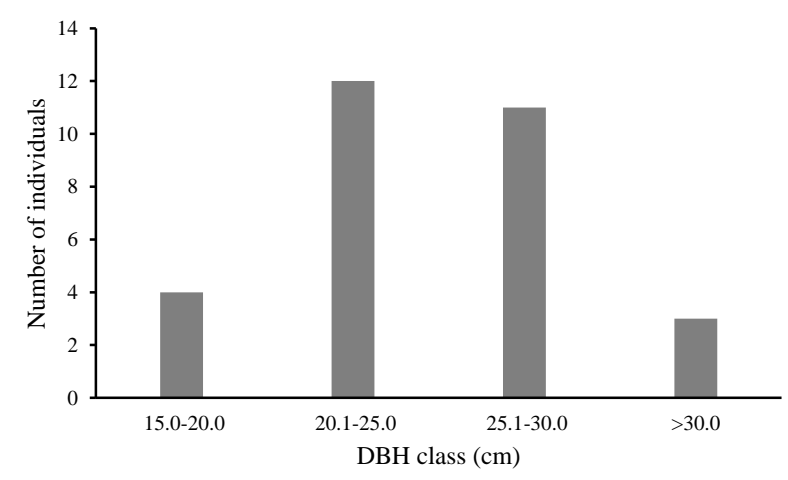

A

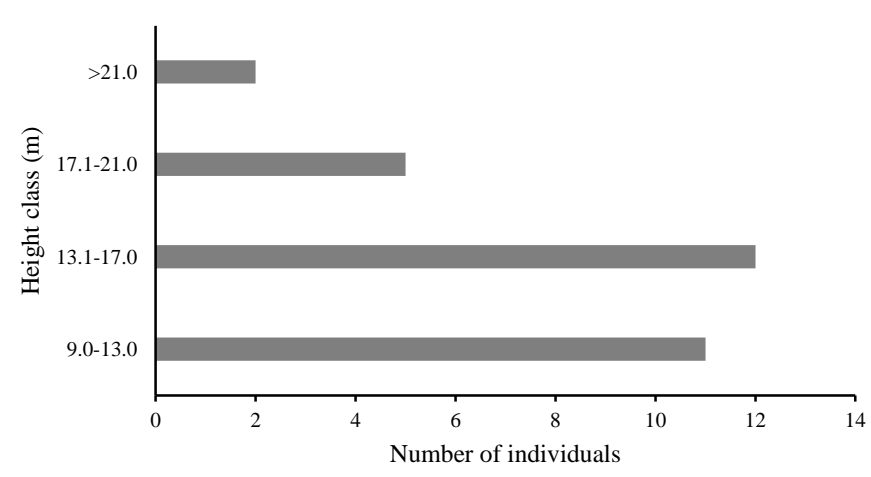

B

Figure 4. The distributions of (A) DBH classes and (B) height classes of sample trees to developed allometric equations 
Table 1. Pearson's correlation between DBH, height, wood density and branches biomass, trunk biomass, TAGB and parameters of destructive biomass

\begin{tabular}{|c|c|c|c|c|c|}
\hline & \multicolumn{3}{|c|}{ Pearson's correlation } & \multirow{2}{*}{ Mean } & \multirow{2}{*}{ Range } \\
\hline & DBH (cm) & H (m) & $\mathrm{WD}\left(\mathrm{g} \mathrm{cm}^{-3}\right)$ & & \\
\hline Leaf biomass $(\mathrm{kg})$ & $-0.303^{\mathrm{ns}}$ & $-0.198^{\mathrm{ns}}$ & $0.262^{\text {ns }}$ & 12.43 & $1.37-45.59$ \\
\hline Branch biomass (kg) & $0.205^{\mathrm{ns}}$ & $-0.072^{\mathrm{ns}}$ & $0.208^{\mathrm{ns}}$ & 16.99 & $3.92-34.18$ \\
\hline Trunk biomass (kg) & $0.527^{* *}$ & $0.768^{* *}$ & $0.027^{\mathrm{ns}}$ & 116.55 & $12.84-296.72$ \\
\hline TAGB $(\mathrm{kg})$ & $0.494^{*}$ & $0.710^{* *}$ & $0.098^{\mathrm{ns}}$ & 145.97 & $34.28-308.98$ \\
\hline $\mathrm{DBH}(\mathrm{cm})$ & 1 & $0.578^{* *}$ & $-0.357^{\mathrm{ns}}$ & 24.35 & $16.00-32.00$ \\
\hline $\mathrm{H}(\mathrm{m})$ & $0.578^{* *}$ & 1 & $-0.184^{\mathrm{ns}}$ & 14.54 & $9.30-22.70$ \\
\hline $\mathrm{WD}\left(\mathrm{g} \mathrm{cm}^{-3}\right)$ & $-0.357^{\mathrm{ns}}$ & $-0.184^{\mathrm{ns}}$ & 1 & 0.53 & $0.37-0.69$ \\
\hline
\end{tabular}

Note: ${ }^{n s}$ : is not significant at the 0.05 level $(\mathrm{P}>0.05) ;{ }^{*}$ and ${ }^{* *}$ Correlation are significant at the 0.05 and 0.01 level (2-tailed) respectively

Table 2. All data sets for develop allometric equations in abandoned lands

\begin{tabular}{|c|c|c|c|c|c|c|c|c|c|}
\hline $\begin{array}{l}\text { Tree } \\
\text { No. }\end{array}$ & Family & Species & $\begin{array}{r}\text { DBH } \\
(\mathbf{c m})\end{array}$ & $\begin{array}{l}\mathbf{H} \\
(\mathbf{m})\end{array}$ & $\begin{array}{c}\text { Leaves } \\
\text { (kg) }\end{array}$ & $\begin{array}{c}\text { Branches } \\
\text { (kg) }\end{array}$ & $\begin{array}{c}\text { Trunk } \\
\text { (kg) }\end{array}$ & $\begin{array}{c}\text { TAGB } \\
(\mathrm{kg})\end{array}$ & $\begin{array}{c}\text { WD } \\
\left(\mathrm{g} \mathrm{cm}^{-3}\right)\end{array}$ \\
\hline 1 & Malvaceae & Pterospermum javanicum & 31.85 & 18.10 & 5.68 & 32.61 & 249.73 & 288.01 & 0.53 \\
\hline 2 & Malvaceae & Pterospermum javanicum & 20.06 & 17.10 & 9.31 & 9.39 & 119.09 & 137.80 & 0.53 \\
\hline 3 & Malvaceae & Pterospermum javanicum & 28.98 & 22.70 & 3.86 & 8.39 & 296.72 & 308.98 & 0.53 \\
\hline 4 & Moraceae & Ficus septica & 32.17 & 20.20 & 5.70 & 19.70 & 166.63 & 192.03 & 0.39 \\
\hline 5 & Moraceae & Ficus septica & 28.03 & 15.60 & 1.92 & 10.47 & 93.98 & 106.38 & 0.39 \\
\hline 6 & Cannabaceae & Trema orientalis & 26.75 & 14.16 & 7.37 & 22.89 & 86.11 & 116.36 & 0.44 \\
\hline 7 & Proteaceae & Heliciopsis artocarpoides & 21.97 & 9.70 & 9.95 & 9.88 & 57.62 & 77.44 & 0.65 \\
\hline 8 & Phyllanthaceae & Bridelia glauca & 28.66 & 13.90 & 6.78 & 12.37 & 80.76 & 99.91 & 0.50 \\
\hline 9 & Phyllanthaceae & Bridelia glauca & 20.70 & 12.50 & 6.93 & 16.74 & 71.55 & 95.22 & 0.50 \\
\hline 10 & Cannabaceae & Trema orientalis & 26.11 & 10.80 & 13.97 & 29.02 & 58.17 & 101.16 & 0.44 \\
\hline 11 & Malvaceae & Pterospermum javanicum & 29.62 & 16.00 & 8.76 & 10.12 & 77.63 & 96.52 & 0.53 \\
\hline 12 & Malvaceae & Pterospermum javanicum & 16.88 & 10.60 & 6.88 & 14.56 & 12.84 & 34.28 & 0.53 \\
\hline 13 & Phyllanthaceae & Bridelia glauca & 26.75 & 15.80 & 12.89 & 33.00 & 89.17 & 135.07 & 0.50 \\
\hline 14 & Euphorbiaceae & Glochidion obscurum & 26.00 & 15.30 & 10.65 & 8.34 & 114.02 & 133.01 & 0.67 \\
\hline 15 & Euphorbiaceae & Glochidion obscurum & 20.40 & 13.70 & 11.88 & 9.24 & 89.41 & 110.53 & 0.67 \\
\hline 16 & Fabaceae & Archidendron jiringa & 16.00 & 10.36 & 22.95 & 9.27 & 24.09 & 56.30 & 0.42 \\
\hline 17 & Dipterocarpaceae & Vatica javanica & 19.95 & 13.00 & 38.71 & 32.40 & 43.01 & 114.11 & 0.69 \\
\hline 18 & Euphorbiaceae & Glochidion obscurum & 19.70 & 14.65 & 8.64 & 14.25 & 78.32 & 101.21 & 0.67 \\
\hline 19 & Fabaceae & Archidendron jiringa & 24.60 & 16.00 & 45.59 & 22.73 & 160.89 & 229.21 & 0.42 \\
\hline 20 & Dipterocarpaceae & Vatica javanica & 20.70 & 12.00 & 39.17 & 16.92 & 129.92 & 186.01 & 0.69 \\
\hline 21 & Euphorbiaceae & Glochidion obscurum & 20.39 & 9.50 & 20.97 & 34.18 & 104.42 & 159.57 & 0.67 \\
\hline 22 & Dipterocarpaceae & Vatica javanica & 28.60 & 13.90 & 7.66 & 29.95 & 184.53 & 222.14 & 0.69 \\
\hline 23 & Euphorbiaceae & Glochidion obscurum & 21.50 & 10.90 & 11.24 & 21.63 & 142.13 & 175.00 & 0.67 \\
\hline 24 & Moraceae & Artocarpus elasticus & 32.60 & 20.70 & 14.15 & 20.23 & 183.51 & 217.89 & 0.46 \\
\hline 25 & Asteraceae & Vernonia arborea & 23.30 & 9.82 & 1.37 & 3.92 & 52.70 & 57.99 & 0.37 \\
\hline 26 & Asteraceae & Vernonia arborea & 29.40 & 13.50 & 3.79 & 9.83 & 121.02 & 134.64 & 0.37 \\
\hline 27 & Phyllanthaceae & Bridelia glauca & 21.50 & 9.30 & 14.28 & 17.31 & 67.24 & 98.83 & 0.50 \\
\hline 28 & Malvaceae & Pterospermum javanicum & 20.29 & 16.10 & 4.04 & 3.94 & 163.39 & 171.38 & 0.53 \\
\hline 29 & Malvaceae & Pterospermum javanicum & 20.36 & 18.50 & 6.66 & 8.55 & 189.90 & 205.12 & 0.53 \\
\hline \multirow[t]{5}{*}{30} & Malvaceae & Pterospermum javanicum & 26.60 & 21.70 & 11.19 & 17.72 & 187.95 & 216.85 & 0.53 \\
\hline & Average & & 24.35 & 14.54 & 12.43 & 16.99 & 116.55 & 145.96 & 0.53 \\
\hline & Minimum & & 16.00 & 9.30 & 1.37 & 3.92 & 12.84 & 34.28 & 0.37 \\
\hline & Maximum & & 32.60 & 22.70 & 45.59 & 34.18 & 296.72 & 308.98 & 0.69 \\
\hline & Standard deviation & & 4.66 & 3.75 & 10.93 & 9.13 & 65.59 & 66.98 & 0.11 \\
\hline
\end{tabular}

Note: $\mathrm{DBH}=$ diameter at breast height; $\mathrm{H}=$ total height; $\mathrm{TAGB}=$ total above ground biomass; $\mathrm{WD}=$ =ood density

Thirty sample trees with DBH of $>15 \mathrm{~cm}$ were selected in the study site, with consideration of the species. These selected trees did not consider individuals with damaged crowns or broken trunks. Almost $90 \%$ of the selected trees were categorized as the dominant species in terms of density and Importance Value Index (IVI) as observed in the current study, while few selected trees represented the rare species. There were 10 species of 10 genera of 9 families selected in study site. Eight sample trees were Pterospermum javanicum (Malvaceae). There were 5 sample trees of Glochidion obscurum (Euphorbiaceae) and 4 sample trees of Bridelia glauca (Phyllanthaceae). Three sample trees were Vatica javanica (Dipterocarpaceae). The species of Ficus septica (Moraceae), Trema orientalis 
(Cannabaceae), Archidendron jiringa (Fabaceae), Vernonia arborea (Asteraceae) were selected for two sample trees respectively. One sample tree was Heliciopsis artocarpoides (Proteaceae) as well as Artocarpus elasticus (Moraceae). The range of dry weight was $1.37-45.59 \mathrm{~kg}$ for leaf, $3.92-34.18 \mathrm{~kg}$ for branch, $12.84-296.72 \mathrm{~kg}$ for trunk, and $34.28-308.98 \mathrm{~kg}$ for TAGB in this site (Table 2). The result showed that there are diverse variations among different species. The different tree species tend to has a different structure (growth, stratification, and crown cover) and physiognomy. The largest sample tree was A. elasticus with DBH of $32.60 \mathrm{~cm}$. This species had the dry weight of leaf, branch, trunk, and TAGB was 14.15, 20.23, 183.51, and $217.89 \mathrm{~kg}$ respectively. On the other hand, the smallest selected tree was $A$. jiringa with DBH of $16.00 \mathrm{~cm}$. This species obtained $22.95 \mathrm{~kg}$ of leaf dry biomass, $9.27 \mathrm{~kg}$ of branch dry biomass, $24.09 \mathrm{~kg}$ of trunk dry biomass, and $56.30 \mathrm{~kg}$ of TAGB. P. javanicum with $22.70 \mathrm{~m}$ height was the tallest sample trees. This sample tree had the highest trunk dry biomass $(296.72 \mathrm{~kg}$ ) and TAGB (308.98 kg). Contrastly, the other sample tree of $P$. javanicum had the lowest trunk dry biomass $(12.84 \mathrm{~kg})$ and TAGB $(34.28 \mathrm{~kg})$. The shortest sample tree with $9.30 \mathrm{~m}$ height was $B$. glauca. The lowest leaf dry biomass $(1.37 \mathrm{~kg})$ and branch dry biomass $(3.92 \mathrm{~kg}$ ) were showed by $V$. arborea. Meanwhile, the other sample tree of $A$. jiringa had the highest leaf dry biomass $(45.59 \mathrm{~kg})$. The highest branch dry biomass $(34.18$ $\mathrm{kg}$ ) was shown by $G$. obscurum.

\section{The developed allometric equations}

The results of regression analyses for predicting plant part biomass of subject trees from diameter at breast height (DBH) and total height $(\mathrm{H})$ using data all studied individuals are shown in Table 3. The relationships between DBH, $\left(\mathrm{DBH}^{2} \times \mathrm{H}\right)$, and height of trees as independent variables were not significant to related leaf and branch dry biomass (P-value $>0.05$ ) as well as DBH to trunk dry biomass. This means that the DBH, $\left(\mathrm{DBH}^{2} \times \mathrm{H}\right)$, height of trees were not a good predictor of leaf and branch dry biomass based on the goodness of fit. Similarly, DBH was not also good predictor of trunk dry biomass. The correlations between $\left(\mathrm{DBH}^{2} \times \mathrm{H}\right)$ and height of trees to trunk dry biomass and TAGB showed moderately strong relationships as well as DBH to TAGB $(P$-value $<0.001)$.

The selected allometric equations to estimate above ground biomass of trees were dominated by log-linear model $(\ln \mathrm{y}=\mathrm{a}+\mathrm{b} \ln \mathrm{x})$ and linear model $(\mathrm{y}=\mathrm{a}+\mathrm{bx})$. These equations were fitting model to relate dependent variables (leaf, branch, trunk, and AGB) and independent variables $\left(\mathrm{DBH},\left(\mathrm{DBH}^{2} \times \mathrm{H}\right)\right.$, and $\left.\mathrm{H}\right)$ for tree stage. From all tested regression, there are only four equations with relatively high $R^{2}(>0.400)$. These equations are "ln (trunk dry biomass $)=0.837 \times \ln \left(\mathrm{DBH}^{2} \times \mathrm{H}\right)-29.45$ " $\left(R^{2}=0.500\right)$, "ln $($ trunk dry biomass $)=1.812 \times \ln (\mathrm{H})-0.217$ " $\left(\mathrm{R}^{2}=0.461\right)$, "ln $(\mathrm{AGB})=0.576 \times \ln \left(\mathrm{DBH}^{2} \times \mathrm{H}\right)-0.301 "\left(R^{2}=0.431\right)$, and "ln $(\mathrm{AGB})=1.331 \times \ln (\mathrm{H})-1.350 "\left(R^{2}=0.455\right)$. However, the result showed there are very weak relationships between leaves and branches dry biomass of trees and plant dimensions in the abandoned land. The trunk dry biomass and AGB in the tropical secondary forests of different ages (5, 10 and 20 years after abandonment) showed strong correlations (adjusted $R^{2}=$ 0.59-0.95) with diameter at breast height (DBH) and height. The leaf and branch dry biomass had weak correlations with height (adjusted $R^{2}=0.36-0.50$ ) (Karyati et al. 2019). The mixed-species allometric equations showed AGB correlates significantly with diameter at stump height $\left(R^{2}=0.78 ; \quad P<0.01\right)$ and tree height $\left(R^{2}=0.41, \quad P<0.05\right)$ (Mokria et al. 2018). Generally, the developed allometric equations showed relatively low $R^{2}(<0.60)$. This may be caused by the high variation sample trees. The variation sample trees lead the variation in wood density, structure, and physiognomy. Parlucha (2017) stated that comparing growth performance for different levels of species type (native or exotic) is not conclusive since the growth of trees varies. It happens from specific species character level and matching with the existing site condition. The regression between the trunk biomass and TAGB and the product of square DBH and height $\left(\mathrm{cm}^{2} \mathrm{~m}\right)$ and the natural logarithm of height were illustrated in Figure 6.

Table 3. The allometric equations for predicting plant part biomass of subject trees in the study site

\begin{tabular}{|c|c|c|c|c|c|c|c|}
\hline $\begin{array}{l}\text { Dependent } \\
\text { variable }(y)\end{array}$ & $\begin{array}{l}\text { Independent variable } \\
(\mathbf{x})\end{array}$ & Equation & $P$ value & $R^{2}$ & MPE & MRE & MRAE \\
\hline Leaf dry & DBH $(\mathrm{cm})$ & $\ln y=0.054-3.524 x$ & $>0.05$ & 0.099 & 0.047 & 0.299 & 0.292 \\
\hline \multirow[t]{2}{*}{ biomass (kg) } & $\left(\mathrm{DBH}^{2} \times \mathrm{H}\right)\left(\mathrm{cm}^{2} \mathrm{~m}\right)$ & $\ln y=0.4132-5.932 \ln x$ & $>0.05$ & 0.086 & 0.252 & 0.321 & 0.291 \\
\hline & $\mathrm{H}(\mathrm{m})$ & $y=0.001-17.614 x$ & $>0.05$ & 0.074 & 0.269 & 0.393 & 0.306 \\
\hline Branch dry & $\mathrm{DBH}(\mathrm{cm})$ & $\ln y=0.695+0.4687 \ln x$ & $>0.05$ & 0.060 & 0.150 & 0.220 & 0.284 \\
\hline \multirow[t]{2}{*}{ biomass (kg) } & $\left(\mathrm{DBH}^{2} \times \mathrm{H}\right)\left(\mathrm{cm}^{2} \mathrm{~m}\right)$ & $\ln y=0.001+2.5228 x$ & $>0.05$ & 0.023 & 0.172 & 0.291 & 0.290 \\
\hline & $\mathrm{H}(\mathrm{m})$ & $y=0.001+15.097 x$ & $>0.05$ & 0.014 & 0.202 & 0.170 & 0.311 \\
\hline Trunk dry & $\mathrm{DBH}(\mathrm{cm})$ & $\ln y=1.910-1.501 \ln x$ & $>0.05$ & 0.347 & 0.174 & 0.163 & 0.289 \\
\hline \multirow[t]{2}{*}{ biomass $(\mathrm{kg})$} & $\left(\mathrm{DBH}^{2} \times \mathrm{H}\right)\left(\mathrm{cm}^{2} \mathrm{~m}\right)$ & $\ln y=0.837-2.945 \ln x$ & $<0.001$ & 0.500 & 0.030 & 0.371 & 0.291 \\
\hline & $\mathrm{H}(\mathrm{m})$ & $\ln y=1.812-0.217 \ln x$ & $<0.001$ & 0.461 & 0.033 & 0.072 & 0.289 \\
\hline \multirow{3}{*}{$\begin{array}{l}\text { Above ground } \\
\text { biomass }(\mathrm{kg})\end{array}$} & $\mathrm{DBH}(\mathrm{cm})$ & $\ln y=1.277+0.808 \ln x$ & $<0.001$ & 0.283 & 0.130 & 0.210 & 0.357 \\
\hline & $\left(\mathrm{DBH}^{2} \times \mathrm{H}\right)\left(\mathrm{cm}^{2} \mathrm{~m}\right)$ & $\ln y=0.576-0.301 \ln x$ & $<0.001$ & 0.431 & 0.070 & 0.144 & 0.289 \\
\hline & $\mathrm{H}(\mathrm{m})$ & $\ln \mathrm{y}=1.331-1.350 \ln \mathrm{x}$ & $<0.001$ & 0.455 & 0.071 & 0.146 & 0.290 \\
\hline
\end{tabular}

Note: $P$ values of the regression analysis are shown, $R^{2}$ coefficient of determination, MPE mean prediction error, MRE mean relative error, MRAE mean relative absolute error, DBH diameter at breast height, $\mathrm{H}$ tree height. 

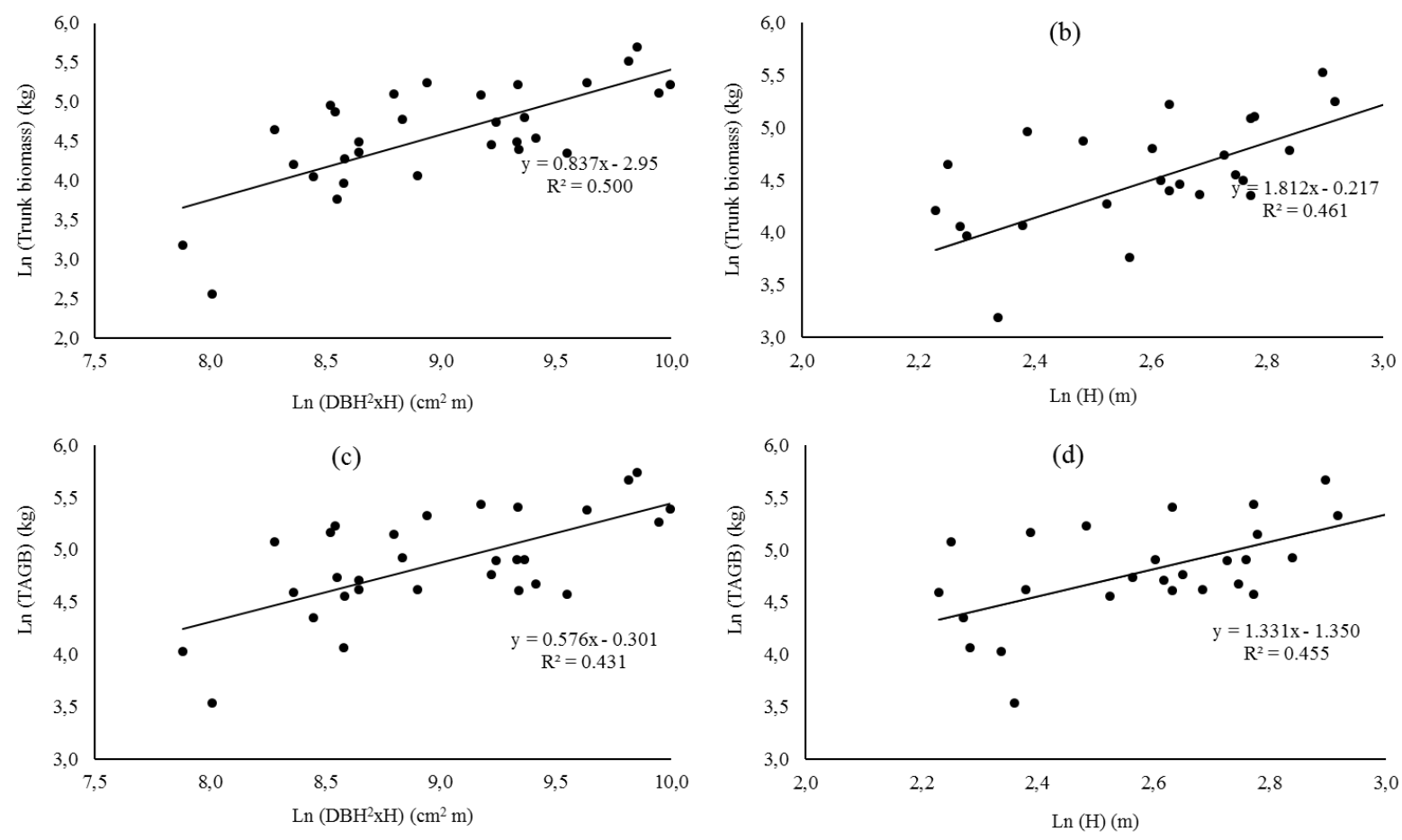

Figure 6. Regression between the trunk biomass $(\mathrm{kg})$ and the product of square DBH and height $\left(\mathrm{cm}^{2} \mathrm{~m}\right)(\mathrm{A})$ and the natural logarithm of height (m) (B); Regression between total above ground biomass (TAGB) $(\mathrm{kg})$ and the product of square DBH and height $\left(\mathrm{cm}^{2} \mathrm{~m}\right)(\mathrm{C})$ and the natural logarithm of height $(\mathrm{m})(\mathrm{D})$.

The results showed that mean prediction errors (MPEs) of the developed aboveground biomass models ranged $4.7 \%$ to $26.9 \% \%$. These values were higher than reported by Zeng et al. (2017). Zeng et al. (2017) stated that mean prediction errors (MPEs) of the developed one- and twovariable aboveground biomass models were less than $4 \%$. The mean relative errors (MRE) for predicting plant part biomass of subject trees in the study site ranged from $7.2 \%$ to $39.3 \%$. This MRE was also higher than reported for lowland tropical forests of the Indo-Malay region (MRE ranged $3.2 \%$ to $33.6 \%$ ) (Manuri et al. 2017). The mean relative absolute error (MRAE) of developed allometric equations ranged from $28.4 \%$ to $35.7 \%$. Similarly, the range of MRAE for aboveground biomass models was 26.6-41.5\% as reported by Manuri et al. (2017).

\section{Comparison among various allometric equations}

The estimation of AGB using the developed allometric equation in this study was lower than using the previously developed equations as presented in Table 3. The AGB estimation of $33.31 \mathrm{Mg} \mathrm{ha}^{-1}$ was lower than $115.90,91.65$, 85.60, 76.31, 70.39, 68.08, 63.99, 60.32 $\mathrm{Mg} \mathrm{ha}^{-1}$ of AGB calculated using the formulas of Rai and Proctor (1986), Chambers et al. (2001), Yamakura et al. (1986), Brown (1997), Manuri et al. (2017), Basuki et al. (2009), Kiyono and Hastaniah (2008), and Nelson et al. (1999) respectively. The value resulted by the developed allometric equation was similar than those using other previous reported equations, i.e., $38.86 \mathrm{Mg} \mathrm{ha}^{-1}$ (Kenzo et al. 2009a), $39.31 \mathrm{Mg} \mathrm{ha}^{-1}$ (Hashimoto et al. 2004), 49.05
$\mathrm{Mg} \mathrm{ha}^{-1}$ (Sierra et al. (2007), $49.63 \mathrm{Mg} \mathrm{ha}^{-1}$ (Kettering et al. 2001), 50.31 $\mathrm{Mg} \mathrm{ha}^{-1}$ (Karyati et al. 2019), and $5.94 \mathrm{Mg} \mathrm{ha}^{-1}$ (Kenzo et al. 2009b). The comparison between AGB and DBH estimated by previously reported relationships was illustrated in Figure 7.

The calculation using equations of Rai and Proctor (1986), Chambers et al. (2001), Yamakura et al. (1986), Brown (1997), Basuki et al. (2009), and Kiyono and Hastaniah (2008) resulted in the overestimation than the developed allometric equation. This might be caused by the low wood density (0.37-0.69) of trees in the study site, because tree species observed in the abandoned land was dominated by pioneer species. The allometric equations for pioneer species may differ significantly caused usually these species have low wood (Hashimoto et al. 2004). The wood densities of trees were 0.40-0.79 for Brown's equation, 0.32-0.86 for Basuki et al.'s equation, and 0.67 for Kiyono and Hastaniah's equation. The similar values of AGB were estimated by using equations of Kenzo et al. (2009a) with wood density of 0.35 , Kettering et al. (2001) with wood density of 0.35 to 0.91 , Karyati et al. (2019) with wood density of 0.24-0.44, and Kenzo et al. (2009b) with wood density of 0.35 . Kenzo et al. (2009a), Hashimoto et al. (2004), and Karyati et al. (2019) developed allometric equation for mixed species in tropical forest of Kalimantan, while Kettering et al. (2001) developed allometric for mixed secondary forest in Sumatra. Sierra et al. (2007) reported allometric equation for tropical forests in Colombia. The similar tree species in abandoned land of study site and the mixed secondary 
forest caused a similar estimation of AGB by using the developed equations. The species and stand characteristics such as wood density and tree height effected to AGB variation directly, meanwhile, biogeographical region only slightly effected the accuracy of AGB equations (Manuri et al. 2017). In addition, aboveground biomass was also related to mean annual temperature (MAT) (Zeng et al. 2017).

In conclusion, this study provides allometric equations to estimate above ground biomass in the tropical abandoned lands after selective logging that characterized by mixed species. The specific allometric equation for different types of abandoned lands was needed. Because the using appropriate allometric model will determine the accurate estimation of above ground biomass in the site.

\section{ACKNOWLEDGEMENTS}

We express our thanks to Ministry of Research, Technology and Higher Education, Republic of Indonesia for supporting Hibah Penelitian Dasar Unggulan Perguruan Tinggi Contract No.: 183/SP2H/LT/DRPM/2019.

Table 4. Estimation of AGB using various reported relationships for trees in the study site

\begin{tabular}{|c|c|c|}
\hline Equation & Author & Estimate of AGB $\left(\mathrm{Mg} \mathrm{ha}^{-1}\right)$ \\
\hline $\ln (\mathrm{AGB})=2.12 \times \ln (\mathrm{DBH})-0.435$ & Rai and Proctor (1986) & 115.90 \\
\hline $\ln (\mathrm{AGB})=2.62 \times \ln (\mathrm{DBH})-2.30$ & Yamakura et al. (1986) & 85.60 \\
\hline $\ln (\mathrm{AGB})=2.53 \times \ln (\mathrm{DBH})-2.13$ & Brown (1997) & 76.31 \\
\hline $\ln (\mathrm{AGB})=2.413 \times \ln (\mathrm{DBH})-1.997$ & Nelson et al. (1999) & 60.32 \\
\hline $\ln (A G B)=2.55 \times \ln (\mathrm{DBH})-2.010$ & Chambers et al. (2001) & 91.65 \\
\hline $\ln (\mathrm{AGB})=2.59 \times \ln (\mathrm{DBH})-2.75$ & Kettering et al. (2001) & 49.63 \\
\hline $\ln (\mathrm{AGB})=2.44 \times \ln (\mathrm{DBH})-2.51$ & Hashimoto et al. (2004) & 39.31 \\
\hline $\ln (\mathrm{AGB})=2.422 \times \ln (\mathrm{DBH})-2.232$ & Sierra et al. (2007) & 49.05 \\
\hline $\mathrm{AGB}=0.1008 \times \mathrm{DBH}^{2.5264}$ & Kiyono and Hastaniah (2008) & 63.99 \\
\hline $\ln (A G B)=2.196 \times \ln (\mathrm{DBH})-1.201$ & Basuki et al. (2009) & 68.08 \\
\hline $\mathrm{AGB}=0.0829 \times \mathrm{DBH}^{2.43}$ & Kenzo et al. (2009a) & 38.86 \\
\hline $\mathrm{AGB}=0.1525 \times \mathrm{DBH}^{2.34}$ & Kenzo et al. (2009b) & 53.94 \\
\hline $\mathrm{AGB}=0.071 \times \mathrm{DBH}^{2.667}$ & Manuri et al. (2017) & 70.39 \\
\hline $\ln (\mathrm{AGB})=2.3207 \times \ln (\mathrm{DBH})-1.89$ & Karyati et al. (2019) & 50.31 \\
\hline$(\mathrm{AGB})=12.683 \times\left(\mathrm{DBH}^{2} \times \mathrm{H}\right)-38.403$ & This study & 33.31 \\
\hline
\end{tabular}

Note: $\mathrm{AGB}=$ above ground biomass $; \mathrm{DBH}=$ diameter at breast height

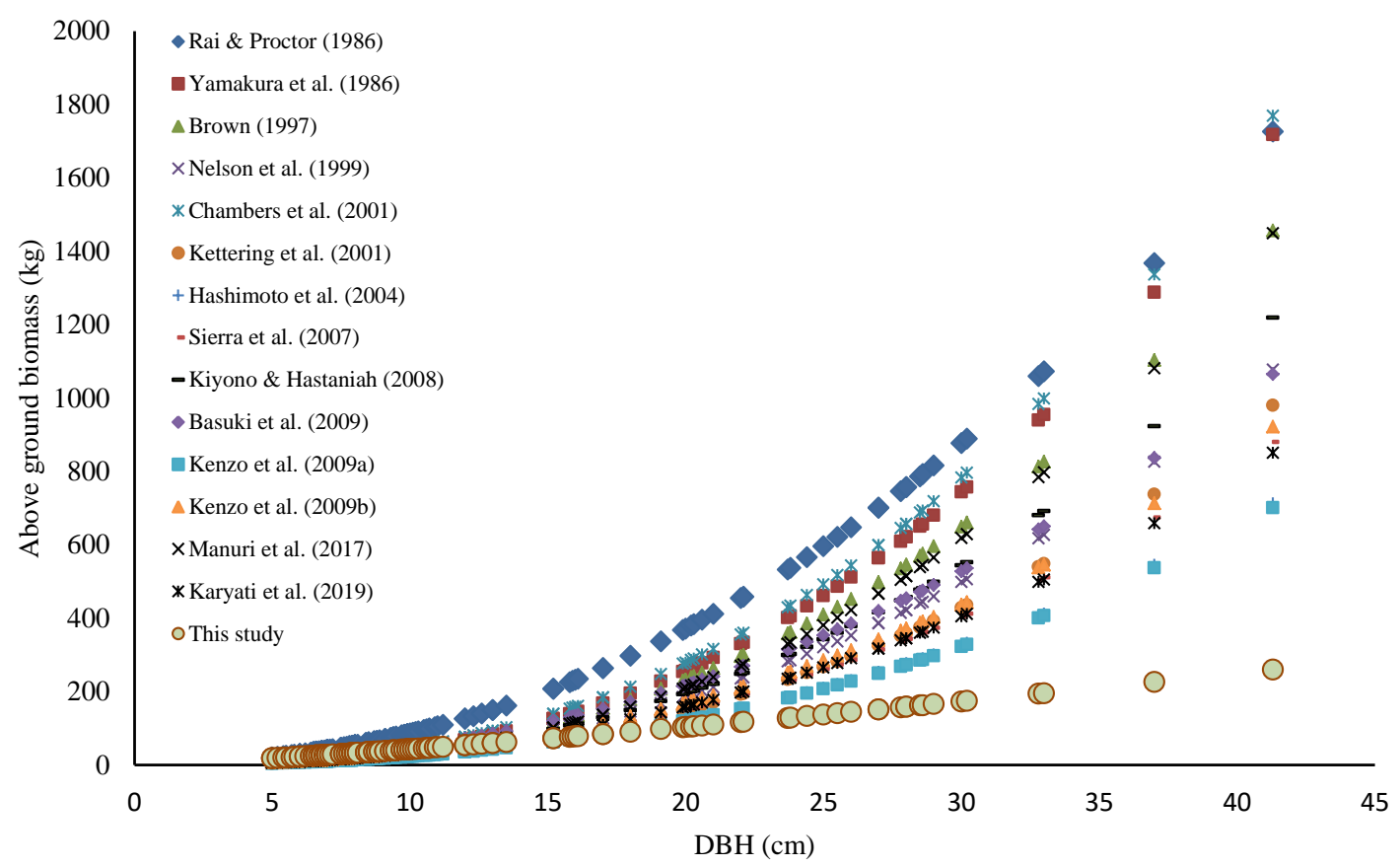


Figure 7. Comparison among various allometric relationships between above ground biomass (AGB) and diameter at breast height $(\mathrm{DBH})$ in the study site

\section{REFERENCES}

Awang Noor AG, Faridah Hanum I, Tuan Marina TI. 2008. Relationship between economic value and species diversity of timber resources in a hill forest in Peninsular Malaysia. J Sustain Dev 1 (2): 17-26.

Basuki TM, Van Laake PE, Skidmore AK, Hussin YA. 2009. Allometric equations for estimating the above-ground biomass in tropical lowland dipterocarp forest. For Ecol Manag 257: 1684-1694.

Brown S. 1997. Estimating Biomass and Biomass Change in Tropical Forest: A Primer. Food and Agriculture Organization of the United Nations, Rome.

Chamber JQ, Santos JD, Ribeiro RJ, Higuchi N. 2001. Tree damage, allometric relationship, and above-ground net primary production in Central Amazon forest. For Ecol Manag 152: 73-84.

Chokkalingam U, Smith J, de Jong W. 2001. A conceptual framework for the assessment of tropical secondary forest dynamics and sustainable development potential in Asia. J Trop For Sci 13 (4): 577-600.

Curtis PS. 2008. Estimating Aboveground Carbon in Live and Standing Dead Trees. In: Hoover CM (ed). Field Measurements for Forest Carbon Monitoring: a Landscape-Scale Approach. Springer, USA.

Fearnside PM. 1997. Greenhouse gases emissions from deforestation in Brazillian Amazonia: Net committed emissions. Clim Ch 35: 321360 .

Gorte RW. 2007. Carbon Sequestration in Forests. CRS Report for Congress. Congressional Research Service.

Hairiah K, Rahayu S. 2007. Pengukuran "Karbon Tersimpan" di Berbagai Macam Penggunaan Lahan. World Agroforestry Centre-ICRAF, Indonesia.

Hairiah K, Sitompul SM, Van Noordwijk M, Palm C. 2001. Methods for Sampling Carbon Stocks Above and Below Ground. ASB Lecture Note 4B. International Centre for Research in Agroforestry, Indonesia.

Harmon EH, Ferrell WK, Franklin JF. 1990. Effects on carbon storage of conservation of old growth forests to young forests. Science 297: 699702 .

Hashimoto T, Tange T, Masumori M, Yagi H, Sasaki S, Kojima K. 2004. Allometric equations for pioneer tree species and estimation of the aboveground biomass of a tropical secondary forest in East Kalimantan. Tropics 14: 123-130.

Janisch JE, Harmon ME. 2002. Successional changes in live and dead wood carbon stores: Implications for net ecosystem productivity. Tree Physiol 22: 77-89.

Karyati, Ipor IB, Jusoh I, Wasli ME. 2019. Allometric equations to estimate the above-ground biomass of trees in the tropical secondary forests of different ages. Biodiversitas 20 (9): 2427-2436.

Karyati. 2013. Ecology and Carbon Sequestration of Secondary Forests at

Sabal, Sarawak. [Dissertation]. Universiti Malaysia Sarawak, Malaysia.

Kendawang JJ, Ninomiya I, Tanaka K, Ozawa T, Hattori D, Tanaka S, Sakurai K. 2007. Effects of burning strength in shifting cultivation on the early stage of secondary succession in Sarawak, Malaysia. Tropics 16: 309-321.

Kenzo T, Furutani R, Hattori D, Kendawang JJ, Tanaka S, Sakurai K, Ninomiya I. 2009a. Allometric equations for accurate estimation of above-ground biomass in logged-over tropical rainforests in Sarawak, Malaysia. J For Res 14 (6): 365-372.

Kenzo T, Ichie T, Hattori D, Itioka T, Handa C, Ohkubo T, Kendawang JJ, Nakamura M, Sakaguchi M, Takahashi N, Okamoto M, TanakaOda A, Sakurai K, Ninomiya I. 2009b. Development of allometric relationships for accurate estimation of above- and below-ground biomass in tropical secondary forests in Sarawak, Malaysia. J Trop Ecol 25: 371-386.

Ketterings QM, Coe R, Van Noordwijk M, Ambagau Y, Palm CA. 2001. Reducing uncertainty in the use of allometric biomass equations for predicting above-ground tree biomass in mixed secondary forests. For Ecol Manag 146: 199-209.

Kiyono Y, Hastaniah. 2005. Pattern of slash-and-burn land use and their effects on forest succession. swidden-land forests in Borneo. Bull For For Prod Res Inst 4: 259-282.

Manuri S, Brack C, Rusolono T, Noor'an F, Verchot L, Maulana SI, Adinugroho WC, Kurniawan H, Sukisno DW, Kusuma GA, Budiman A, Anggono RS, Siregar CA, Onrizal O, Yuniati D, Soraya E. 2017. Effect of species grouping and site variables on aboveground biomass models for lowland tropical forests of the Indo-Malay region. Ann For Sci 74 (23): 1-14.

Ministry of Forestry Indonesia. 2011. Development of Allometric Equations for Estimating Forest Carbon Stocks Based on Field Measurement (Ground Based Forest Carbon Accounting). Centre for Standardization and Environment, Ministry of Forestry, Indonesia.

Mokria M, Mekuria W, Gebrekirstos A, Aynekulu E, Belay B, Gashaw T, Brauning A. 2018. Mixed-species allometric equations and estimation of aboveground biomass and carbon stocks in restoring degraded landscape in northern Ethiopia. Environ Res Lett 13: 1-14.

Moore PD, Chapman SB. 1986. Methods in Plant Ecology. $2^{\text {nd }}$ ed. Blackwell Scientific Publications, Oxford.

Nelson BW, Mesquita R, Pereira JLG, De Souza SGA, Batista T, Couto LB. 1999. Allometric regressions for improved estimate of secondary forest biomass in the Central Amazon. For Ecol Manag 117: 149-167.

Nurlinda I, Pujiwati Y, Ishak M. 2014. Perbandingan penanganan tanah terlantar di Kabupaten Tasikmalaya dan Kabupaten Sukabumi dalam mewujudkan ketahanan pangan Provinsi Jawa Barat. Jurnal Hukum IUS Quia Iustum 21 (1): 120-138. [Indonesian]

Parlucha J, Barbadillo N, Sedenio P. 2017. Species-site matching based on growth performance evaluation of mixed native and exotic secondary forest in Musuan Bukidnon. J Biodiv Environ Sci 10 (3): 62-70.

Pinheiro TF, Escada MIS, Valeriano DN, Hostert P, Gollnow F, Müller H. 2016. Forest degradation associated with logging frontier expansion in the Amazon: The BR-163 Region in Southwestern Pará, Brazil. Earth Interactions 20 (17): 1-26.

Rai SN, Proctor J. 1986. Ecological studies on four rainforest in Karnataka India. J Ecol 76: 938-958.

Roshetko JM, Delaney M, Hairiah K, Purnomosidhi P. 2002. Carbon stocks in Indonesian homegarden systems: Can smallholder systems be targeted for increased carbon storage. Am J Altern Agric 17 (2): 111.

Seiler W, Crutzen PJ. 1980. Estimates of gross and net fluxes of carbon between the biosphere and the atmosphere from biomass burning. Clim Ch 2: 207-247.

Selaya NG, Anten NPR, Oomen RJ, Matthies M, Werger MJA. 2007. Above-ground biomass investments and light interception of tropical forest trees and lianas early in succession. Ann Bot 99: 141-151.

Sierra CA, Del Valle JI, Orrego SA, Moreno FH, Harmon MA, Zapata M, Colorado GJ, Herrera MA, Lara W, Restrepo DE, Berrouet LM, Loaiza LM, Benjumea JF. 2007. Total carbon stocks in a tropical forest landscape of the Porce Region, Colombia. For Ecol Manag 243: 299-309.

Statistics Kutai Kartanegara Regency. 2018. Kutai Kartanegara Regency in Figures 2018. Tenggarong.

Van Do T, Osawa A, Thang NT. 2010. Recovery process of a mountain forest after shifting cultivation in Northwestern Vietnam. For Ecol Manag 259: 1650-1659.

Yamakura T, Hagihara A, Sukardjo S, Ogawa H. 1986. Aboveground biomass of tropical rain forest stands in Indonesian Borneo. Vegetatio 68: 71-82.

Zeng WS, Zhang LJ, Chen XY, Cheng ZC, Ma KX, Li ZH. 2017. Construction of compatible and additive individual-tree biomass models for Pinus tabulaeformis in China. Canadian J For Res 47 (4): 467-475. 